\title{
Alternative phytosanitary products against to white muscardine in Bombyx mori L. (Lepidoptera: Bombycidae)
}

\author{
Produtos fitossanitários alternativos contra a \\ calcinose em Bombyx mori L. (Lepidoptera: Bombycidae)
Rafaela Barbosa Pares 1 , Luis Francisco Angeli Alves ${ }^{1 *}$, Ana Paula Mamprim ${ }^{1}$, Andreia Kusumota Bonini ${ }^{1}$

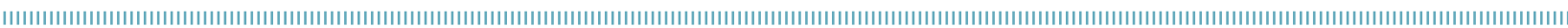

\begin{abstract}
This work aimed to evaluate the effects of the products Biogermex ${ }^{\circledR}$, Agro-mos ${ }^{\circledR}$, Soil-Set $^{\circledR}$ and Planta Clean ${ }^{\circledR}$ on the development of white muscardine in Bombyx mori. Products have been tested at two stages for effects on biology of caterpillars and on silk production (1), and then they were evaluated to know their potential in the prevention/control of white muscardine (2). Products were sprayed on mulberry leaves (preventive treatment) and also on the integument of silkworms (curative treatment). At the first stage, the products were applied on four consecutive days, in one of the daily feeds. Planta Clean ${ }^{\circledR}$ — curative treatment — and Soil-Set ${ }^{\circledR}$ — preventive treatment - caused mortality in $63.3 \%$ and $30 \%$ of silk worms, respectively. The fungus Beauveria bassiana was inoculated at the concentration $5 \times 10^{7}$ conidia $/ \mathrm{mL}$ on the leaves and insects. The products were applied three hours after application on the fungus, in a single application, and also for four days in the other groups. A group of silkworms sprayed only with the fungus served as control. Biogermex ${ }^{\circledR}$ - curative treatment applied once and for four times — was the most effective, reducing mortality by 25 and $26.7 \%$, respectively, as compared with the control group. None of the evaluated products acts preventively against white muscardine.
\end{abstract}

KEYWORDS: silkworm; Beauveria bassiana; disease control.
RESUMO: Este trabalho objetivou avaliar os efeitos de produtos Biogermex ${ }^{\circledR}$, Agro-mos ${ }^{\circledR}$, Soil-Set ${ }^{\circledR}$ e Planta Clean ${ }^{\circledR}$ no desenvolvimento da calcinose branca em Bombyx mori. Os produtos foram testados em duas etapas: efeitos sobre a biologia e produção de seda pela lagarta (1) e, em seguida, em função do seu potencial na prevenção/ no controle da calcinose branca (2). Os produtos foram pulverizados sobre as folhas de amoreira (tratamento preventivo) e sobre o tegumento das lagartas (tratamento curativo). Na primeira etapa, os produtos foram aplicados durante quatro dias consecutivos, em uma das alimentaçóes do dia. Planta Clean ${ }^{\circledR}$ - tratamento curativo - e Soil-Set ${ }^{\circledR}$ - tratamento preventivo - causaram mortalidade em 63,3 e $30 \%$ das lagartas, respectivamente. O fungo Beauveria bassiana foi inoculado na concentração $5 \times 10^{7}$ conídios $/ \mathrm{mL}$ sobre folhas e insetos. Os produtos foram aplicados três horas após o fungo, em uma aplicação, e também por quatro dias em outro grupo. Um grupo de lagartas pulverizadas apenas com fungo serviu como controle. Biogermex ${ }^{\circledR}$ — tratamento curativo aplicado uma e quatro vezes foi o mais eficiente, reduzindo a mortalidade em 25 e $26,7 \%$ respectivamente, em relaçáo ao grupo controle. Nenhum dos produtos avaliados atuou de forma preventiva contra muscardina branca.

PALAVRAS-CHAVE: bicho-da-seda; Beauveria bassiana; controle de doença. 


\section{INTRODUCTION}

Sericulture is an agro-based activity that employs relatively simple and low-tech equipment and facilities. Moreover, the conditions for rearing the insects (humidity around $70 \%$ and temperature of $25^{\circ} \mathrm{C}$ ) are favorable to the development of pathogens that can compromise the whole rearing, especially bacteria, fungi and viruses (PORTO et al., 2005; POTRICH et al., 2007).

White muscardine, the main fungal disease associated with Bombyx mori, is caused by the fungus Beauveria bassiana Bals. (Vuill.), especially in the first instars, and leads to larval death about six days after infection (AMARAL; ALVES, 1979; HANADA; WATANABE, 1986; KUMAR et al., 1999).

Preventive measures, such as disinfecting the premises and equipment, are taken before and after each silkworm batch is removed, followed by the spraying of a $3 \%$ formaldehyde solution (HANADA; WATANABE, 1986; ZANETTI, 2011). It should be noted that, even in the absence of silkworms, and despite all measures of disinfection of the premises and equipment, there is still contamination by microorganisms, although in lower indices, as claimed by MARGATHO et al. (2012).

In this way, PARES; ALVES (2016) reviewed some alternatives to control silkworm white muscardine in $B$. mori silkworms. Besides synthetic fungicides and disinfectants, authors observed some studies with plant extracts and other natural products are being evaluated, and some of them have great potential for use. Therefore, RAJAGOPAL et al. (2014) observed the eficacy of a disinfectant based on chlorothalonil $1.6 \%\left(\right.$ Kavach $\left.^{\circledast}\right)$ to prevent white muscardine in B. mori larvae. Insects infected and treated with the product showed more than $60 \%$ survival.

Aquous extracts of Argemone mexicana, Terminalia arjuna, Syzygium cumini and Annona squamosa, plants with antifungal properties, were evaluated in the prevention of the white muscardine. B. mori larvae were pulverized with $B$. bassiana conidial suspension, followed by extracts application. A reduction in insect mortality by fungus and an increase of cocooning and pupation rates were observed in treated insects (CHAVAN et al., 2011). Also, aqueous extracts of Azadirachta indica, Parthenium hysterophorus, Ocimum sanctum and Pongamia pinnata have been tested on the survival of $B$. mori infected with B. bassiana. A decrease of mortality and an increase of weight in silkworms were verified (NAIK et al., 2016).

Turbinaria conoides algae extract presented antifungal properties when tested in vitro on B. bassiana. Also, it was evaluated in vivo on $B$. mori larvae, previously infected with $B$. bassiana. It was observed the antifungal activity of $T$. conoides extracts, mainly at $2,000 \mu \mathrm{g} / \mathrm{mL}$. There were up to $85 \%$ of cocooning at higher concentrations and only $12 \%$ of cocconing in the group treated with $B$. bassiana (KUMARI et al., 2011).
Recently, it was shown that alternative phytosanitary products (biofertilizer, resistance inducers and plant-based products) may be affected by many biological parameters of B. bassiana, especially the conidial viability (MAMPRIM et al., 2014), though their effect on B. mori silkworms is unclear as far as larval development and silk production are concerned. In this sense, this study aimed to evaluate the potential of alternative phytosanitary products on the development of white muscardine in B. mori.

\section{MATERIAL AND METHODS}

\section{Insects}

Third-instar B. mori silkworms were used in the study (Bratac Fiação de Seda, Guaraniaçu, PR, Brazil). In the laboratory, the silkworms were kept under controlled conditions $\left(26 \pm 1^{\circ} \mathrm{C}\right.$, photoperiod $12 \mathrm{~h}$ ) in plastic boxes, with the bottom lined with paper towel and closed with screened lids. The silkworms were fed with mulberry leaves collected in the morning, and kept in plastic bags at a temperature of $10^{\circ} \mathrm{C}$. Food was provided three times a day, after removal of waste and cleaning of the boxes, until the silkworms would reach the fourth instar, when they were used in the bioassays.

\section{Alternative phytosanitary products}

The experiments were carried out by using products previously selected and assessed by MERTZ et al. (2010) and MAMPRIM et al. (2014) as being incompatible with the fungus $B$. bassiana. The products were used at the concentrations recommended by the manufacturer (Table 1).

\section{Fungus}

The fungus B. bassiana was used as a causative agent of white muscardine, particularly the isolate UNIOESTE 4, from Coleção de Fungos Entomopatogênicos do Laboratório de Biotecnologia Agrícola, Universidade Estadual do Oeste do Paraná in Cascavel, Paraná.

The fungus was grown in culture medium for conidia production (yeast extract $5 \mathrm{~g}$, salt mixture $4.6 \mathrm{~g}$, glucose $10 \mathrm{~g}$, agar $20 \mathrm{~g}$ and water $1,000 \mathrm{~mL}$ ), and incubated at $26^{\circ} \mathrm{C}$ for a 12-hour photoperiod for eight to ten days. Then, the conidia were collected by scraping the surface of the culture medium and stored in a sterile glasstube. After that, $10 \mathrm{~mL}$ of sterile distilled water + Tween $80(0.01 \%)$ was added and serial dilutions were performed for quantification in a Neubauer chamber in order to obtain the concentration of $5 \times 10^{7}$ conidia/ $\mathrm{mL}$, which was previously determined to cause approximately $70 \%$ mortality in silkworm larvae. 


\section{Experiments}

The study was conducted at two stages:

1. Products were evaluated for effects on insect biology and silk production;

2. They were tested for their preventive/curative potential on white muscardine.

Products were applied on the mulberry leaves (preventive action) and on the integument of the silkworms (curative action). The products were applied with a $500 \mathrm{~mL}$ manual sprayer, and the applications were performed once a day (about $4 \mathrm{~mL} /$ repetition). In the control, only sterile distilled water + Tween $80(0.01 \%)$ was sprayed. After application, the silkworms were kept in a temperature-controlled room, as described before. In order to evaluate the effects of alternative products on the biology of $B$. mori and silk production, insects received the products for four consecutive days.

Each treatment used four groups (repetitions) with 15 insects each.

The variables analyzed were: silkworms daily mortality, number of formed cocoons, mean cocoon weight at seven days after formation, mean cocoon shell weight and liquid silk percentage. For such determinations, the cocoons obtained in each treatment were weighed, and then the average unit weight was calculated (g). After that, the cocoons were sectioned longitudinally to extract the pupae and to weight the cocoon shell, and also to determine the mean unit weight of the cocoon shell (g). The liquid silk percentage was calculated with the equation 1 by OLIVEIRA et al. (2010):

Liquid silk percentage $(\%)=\left[\left(\frac{\text { empty coccon weight }}{\text { full coccon weight }}\right) \times 100\right]-24 \%$ (1)

Bioassays were developed in a completely randomized experimental design and in a $4 \times 2$ factorial arrangement, seeking to verify interactions between the four products being tested and the two actions (preventive or curative).

For evaluation of the effects of the products on white muscardine, $5 \mathrm{~mL}$ aliquots of the conidia suspension $\left(5 \times 10^{7}\right.$ conidia $\left./ \mathrm{mL}\right)$ were applied on the mulberry leaves with an airbrush coupled to an air compressor with constant pressure $\left(0.8412 \mathrm{kgf} / \mathrm{cm}^{2}\right)$, while a Potter spray tower was used for the silkworms $\left(0.703 \mathrm{kgf} / \mathrm{cm}^{2}\right)$. Then, the products were applied as preventive and curative treatments. Furthermore, for both treatments, the products were assessed in a singledose application, and then in repeated applications for four consecutive days.

The experiment used a completely randomized design and a $4 \times 2 \times 2$ factorial arrangement, seeking to check interactions between the four products being tested, the two actions, and the two administrations (one administration only or a daily dose for four consecutive days). In the control, only sterile distilled water + Tween $80(0.01 \%)$ was sprayed. There was also a treatment which used fungus suspension alone $\left(5 \times 10^{7}\right.$ conidia $\left./ \mathrm{mL}\right)$.

The evaluation was carried out daily, by removing the dead insects after immersion in a solution of $70 \%$ alcohol and distilled water; they were kept in an incubation chamber for confirmation of the causal agent of mortality. The number of formed cocoons in each treatment was also evaluated.

The hypothesis of normality of the data was confirmed by the Kolmogorov-Smirnov-Lilliefors test $(p>0.05)$. Then, the Dunnett's test $(\mathrm{p}<0.05)$ was used to compare the means of the control and fungus-only group, with data from the groups with alternative phytosanitary products. All statistical analyses were performed with the Statistica 7.0 software (StatSoft, 2004)

\section{RESULTS AND DISCUSSION}

\section{Effect of alternative phytosanitary products on the biology of B. mori and silk production}

When the products were applied to the mulberry leaves to feed the silkworms, there was 30\% mortality in the treatment with Soil-Set ${ }^{\circledast}$. There weren't significative differences between other treatments and control (Table 2).

Soil-Set ${ }^{\circledR}$ is a biofertilizer resulting from the fermentation of organic waste; it has a complex composition of essential nutrients to plants, and some heavy metals that are susceptible to bioaccumulation and, therefore, toxic to insects.

Table 1. Alternate phytosanitary products, mode of action and recommended concentration, used to evaluate the effect of the products on the development and silk production of $B$. mori silkworms.

\begin{tabular}{|c|c|c|c|}
\hline Product & Composition ${ }^{1}$ & Mode of Action ${ }^{1}$ & Recommended concentration $/ \mathrm{ha}^{2}$ \\
\hline Planta Clean ${ }^{\circledR}$ & Vegetals extract and mineral salts & Fungicide & $25 \mathrm{~mL} / 1 \mathrm{LH}_{2} \mathrm{O}$ \\
\hline Soil-Set ${ }^{\circledR}$ & Natural enzymes & Resistance inducer & $100 \mathrm{~mL} / 2 \mathrm{OO} \mathrm{L} \mathrm{H} \mathrm{O}$ \\
\hline Agro-Mos ${ }^{\circledR}$ & $\begin{array}{l}\text { Celular wall from } \\
\text { Saccharomyces cerevisiae/mannanoligosaccharides }\end{array}$ & Resistance inducer & $200 \mathrm{~mL} / 100 \mathrm{~L} \mathrm{H}_{2} \mathrm{O}$ \\
\hline Biogermex ${ }^{\circledR}$ & Citric extracts & Resistance inducer & $200 \mathrm{~mL} / 100 \mathrm{LH}_{2} \mathrm{O}$ \\
\hline
\end{tabular}

'Available information on the label of the products; ${ }^{2}$ Concentration recommended by the manufacturer. 
These features may account for the high mortality rate found in the treatment with this product and, therefore, explain the results. In addition, as any liquid biofertilizer nowadays, SoilSet ${ }^{\circledast}$ has insecticide, insect-repellent, acaricide, and fungicide action (GALLO et al., 2002).

This contrasts from the results with the product Soil-Set ${ }^{\circledR}$ applied on Anticarsia gemmatalis caterpillars (Lepidoptera: Noctuidae), whose mortality rate ranged between 0.8 and $3.2 \%$ (SILVA et al., 2012),

Although, when the products were sprayed on the silkworm integument, the product Planta Clean ${ }^{\circledast}$ caused $63.3 \%$ mortality, while the other treatments were statistically similar to the control (Table 2).

Planta Clean ${ }^{\circledast}$ sprayed on cassava leaves containing cochineal nymphs (Phenacoccus manihoti) (Hemiptera: Pseudococcidae) caused 57\% mortality. However, Planta Clean ${ }^{\circledR}$ was hardly active against $A$. gemmatalis catterpilars (Lepidoptera: Noctuidae), causing only $1.3 \%$ mortality when applied at the recommended concentration on the artificial diet of caterpillars (RHEINHEIMER, 2010; SILVA, 2010).

The action of the insecticide Planta Clean ${ }^{\circledast}$ could be attributed to the presence of plant extracts in its composition (MATTIELO [s.d.]; SILVA, 2010; MAMPRIM et al., 2013).

The low mortality caused by Biogermex ${ }^{\circledR}$ and Agro-mos ${ }^{\circledR}$ was also observed on A. gemmatalis larvae: 5.6 and $3.2 \%$ with Agro-mos ${ }^{\circledast}$ and Biogermex ${ }^{\circledR}$, respectively (SILVA et al., 2012). These results confirm that the product is safe for using in silkworms.

Considering that Planta Clean ${ }^{\circledast}$ proved to be lethal when applied to the integument of the caterpillars and harmless when ingested, and Soil-Set ${ }^{\circledast}$ caused high mortality only when applied on mulberry leaves, the difference in results is likely to be due to morphophysiological mechanisms that ensure certain resistance to toxic compounds.
The first mechanism is the integument itself, which is a mechanical, chemical and biological barrier. The polysaccharides present in the cuticle of insects are lipophilic, while many products are not. It is known that lipophilicity is inversely proportional to product solubility in water; therefore, the more lipophilic the compounds are, given the chemical similarity to the cuticle, the more they penetrate the insect's body at higher rates (GUSMÃO et al., 2000; GALLO et al., 2002).

Given the above, it can be inferred that Soil-Set ${ }^{\circledR}$ did not cause high mortality when applied on the integument, probably because of its low lipophilicity. On the other hand, Planta Clean ${ }^{\circledast}$ has fatty acids in its formulation, which can give the product a lipophilic character, thus facilitating its entry through the integument.

Even if product entry has occurred, however, it is known that insecticide molecules can be eliminated through detoxification. Through this mechanism, insects can modify the insecticide molecule at a rate that prevents its action on the target site by using enzymes from their bodies. Thus, toxic products turn into non-toxic fractions, which can be accumulated in inert forms inside the insect or be readily eliminated from the insect's body (CHAPMAN, 1998).

Soil-Set ${ }^{\circledast}$ showed reverse effect, with high mortality, when ingested. Nevertheless, this may be explained by the product formulation, which is a heavy metal-based biofertilizer whose action is by ingestion, according to MAIRESE (2005).

The high mortality of $B$. mori silkworms in the treatments with Soil-Set ${ }^{\circledR}$ applied on mulberry leaves, and Planta Clean ${ }^{\circledR}$ applied on silkworms, was reflected in the production of cocoons, which was significantly reduced when compared to other groups and also with the control (Table 2).

The treatments with Biogermex ${ }^{\circledR}$ applied on mulberry leaves, and Agro-Mos ${ }^{\circledast}$ applied on silkworms, showed a significant decrease of $13.3 \%$ in the number of cocoons in comparison

Table 2. Mortality cocoon production, cocoon unit weight, cocoon shell unit weight $(\mathrm{g})$ and liquid silk percentage of $B$. mori silkworms subjected to treatment with alternative phytosatinary products daily sprayed on mulberry leaves, and on the silkworms for five days $\left(26 \pm 1{ }^{\circ} \mathrm{C}, 12\right.$ hour photoperiod and relative humidity of $\left.70 \%\right)$.

\begin{tabular}{|c|c|c|c|c|c|c|c|c|c|c|}
\hline \multirow{2}{*}{ Treatment } & \multicolumn{2}{|c|}{ Mortality (\%) } & \multicolumn{2}{|c|}{$\begin{array}{c}\text { Cocoons Formed } \\
(\%)\end{array}$} & \multicolumn{2}{|c|}{$\begin{array}{c}\text { Cocoon Unit Weight } \\
\text { (g) }\end{array}$} & \multicolumn{2}{|c|}{$\begin{array}{c}\text { Cocoon Shell Unit } \\
\text { Weight(g) }\end{array}$} & \multicolumn{2}{|c|}{$\begin{array}{c}\text { Liquid Silk } \\
\text { Percentage (\%) }\end{array}$} \\
\hline & $\begin{array}{l}\text { Mulberry } \\
\text { leaves }\end{array}$ & Silkworm & $\begin{array}{l}\text { Mulberry } \\
\text { leaves }\end{array}$ & Silkworm & $\begin{array}{l}\text { Mulberry } \\
\text { leaves }\end{array}$ & Silkworm & $\begin{array}{l}\text { Mulberry } \\
\text { leaves }\end{array}$ & Silkworm & $\begin{array}{l}\text { Mulberry } \\
\text { leaves }\end{array}$ & Silkworm \\
\hline $\begin{array}{l}\text { Planta } \\
\text { Clean }^{\circledR}\end{array}$ & $\begin{array}{c}5.0 \pm \\
3.2\end{array}$ & $\begin{array}{c}63.3 \pm \\
1.9^{*}\end{array}$ & $\begin{array}{c}93.3 \pm \\
3.9\end{array}$ & $\begin{array}{c}35.0 \pm \\
1.7^{*}\end{array}$ & $\begin{array}{l}1.5 \pm \\
0.03\end{array}$ & & $\begin{array}{l}0.26 \pm \\
0.02 *\end{array}$ & - & $\begin{array}{c}13.2 \pm \\
1.1^{*}\end{array}$ & - \\
\hline Biogermex $^{\circledR}$ & $\begin{array}{c}6.7 \pm \\
2.7\end{array}$ & $\begin{array}{c}8.3 \pm \\
4.2\end{array}$ & $\begin{array}{c}86.7 \pm \\
2.7^{*}\end{array}$ & $\begin{array}{c}91.7 \pm \\
4.2\end{array}$ & $\begin{array}{l}1.5 \pm \\
0.05\end{array}$ & $\begin{array}{l}1.6 \pm \\
0.03\end{array}$ & $\begin{array}{l}0.27 \pm \\
0.02 *\end{array}$ & $\begin{array}{l}0.34 \pm \\
0.03\end{array}$ & $\begin{array}{c}13.7 \pm \\
1.1\end{array}$ & $\begin{array}{c}16.2 \pm \\
1.9\end{array}$ \\
\hline Soil-Set ${ }^{\circledR}$ & $\begin{array}{c}30.0 \pm \\
4.3^{*}\end{array}$ & $\begin{array}{c}5.0 \pm \\
3.2\end{array}$ & $\begin{array}{c}18.3 \pm \\
3.2^{*}\end{array}$ & $\begin{array}{c}93.3 \pm \\
2.7\end{array}$ & - & $\begin{array}{l}1.5 \pm \\
0.03\end{array}$ & - & $\begin{array}{l}0.27 \pm \\
0.06^{*}\end{array}$ & - & $\begin{array}{c}13.8 \pm \\
0.5\end{array}$ \\
\hline Agro-Mos $^{\circledR}$ & $\begin{array}{c}8.3 \pm \\
3.2\end{array}$ & $\begin{array}{c}8.3 \pm \\
3.2\end{array}$ & $\begin{array}{c}90.0 \pm \\
3.3\end{array}$ & $\begin{array}{c}86.6 \pm \\
6.1^{*}\end{array}$ & $\begin{array}{l}1.6 \pm \\
0.08\end{array}$ & $\begin{array}{l}1.5 \pm \\
0.09\end{array}$ & $\begin{array}{c}0.32 \pm \\
0.01\end{array}$ & $\begin{array}{c}0.30 \pm \\
0.02\end{array}$ & $\begin{array}{c}16.1 \pm \\
1.4\end{array}$ & $\begin{array}{c}15.6 \pm \\
1.6\end{array}$ \\
\hline Control & \multicolumn{2}{|c|}{$0 \pm 0$} & \multicolumn{2}{|c|}{$100 \pm 0$} & \multicolumn{2}{|c|}{$1.54 \pm 0.03$} & \multicolumn{2}{|c|}{$0.35 \pm 0.01$} & \multicolumn{2}{|c|}{$17.28 \pm 0.79$} \\
\hline
\end{tabular}

*The data differ statistically from the mean value of the control by Dunnett's test $(p<0.05)$; -: Missing plot. 
with the control. Although mortality was reduced and there was a lack of visible signs of intoxication, some silkworms in the treatment did not encapsulate (Table 2).

However, losses of up to $15 \%$ on sericulture are acceptable, and they occur as a result of low egg-hatching rates, inappropriate shed conditions (temperature, humidity, quality and quantity of offered leaves), etc. (HANADA; WATANABE, 1986).

In sericulture, the silk produced by silkworms is the final product, and the factors associated with their production should be analyzed. In this regard, factors related to insect biology such as survival, growth rate, larval stage duration and longevity are affected by the amount and quality of food ingested by the larvae (PARRA, 1991), and, consequently, it also reflects the quantitative and qualitative production of cocoons.

As for the cocoon unit weight, the values in both applications preventive and curative (mulberry leaves and silkworms) were statistically similar to the value of the control (1.5 g) (Table 2). Similar values (1.54 to $1.64 \mathrm{~g}$ ) were found in comparative studies of mulberry cultivars for B. mori silkworms (PORTO et al., 2003).

However, because of high mortality, there were no cocoons that could be analyzed in the treatment for silkworms with Soil-Set ${ }^{\circledast}$ applied on leaves nor Planta Clean ${ }^{\circledR}$ applied on the silkworms (Table 2).

As for the cocoon shell unit weight, the means ranged from 0.26 to $0.34 \mathrm{~g}$ (Table 2). These data are similar to those found by PORTO et al. (2005), who studied the effect of the extract of Mirabilis jalapa, and found values ranging from 0.36 to $0.38 \mathrm{~g}$.

The treatments with Planta Clean ${ }^{\circledR}$ and Biogermex ${ }^{\circledR}$ applied on mulberry leaves and Soil-Set ${ }^{\circledR}$ applied on silkworm differed from the control; they showed a reduction in the cocoon shell weight (Table 2). To some extent, this decrease can be attributed to the products, which affected the development of the caterpillars and the quality of the produced cocoons (HANADA; WATANABE, 1986).

Similarly, PORTO; OKAMOTO (2000) evaluated the effect of a disinfectant on $B$. mori silkworms, and during the experiment, there were no signs of intoxication; however, the cocoons of the treatments with higher concentrations of the product showed lower cocoonshell weight. Also, OLIVEIRA et al. (2010) observed a reduction in the number of cocoons produced by silkworms fed on mulberry leaves sprayed with alcoholic propolis extract. According to the latter authors, the accumulative action of the products may have caused some intoxication at the end of the cycle, even without visible signs during the experiment.

Regardless of the form of application, the liquid silk percentage produced by caterpillars was similar to the value of the control, with the exception of the Planta Clean ${ }^{\circledR}$ treatment applied on leaves, which resulted in $13.2 \%$ (Table 2).

These values were lower than those ones found by MUNHOZ et al. (2009), in whose study there was an oscillation between 17.4 and $18.7 \%$ of liquid silk produced by B. mori silkworms fed on mulberry leaves of plants that had received organic and chemical fertilizers. OLIVEIRA et al.
(2010) also observed between 16.5 and $17.28 \%$ of liquid silk produced by silkworms treated with leaves containing alcoholic propolis extract. Differences can be due to B. mori races, mulberry varieties, time of year etc., which affect the results.

Thus, the products Biogermex ${ }^{\circledR}$ and Agro-Mos ${ }^{\circledR}$ in both application (preventive application on mulberry leaves and curative application on the integument of the silkworms), Planta Clean ${ }^{\circledR}$ used only as a prevention, and Soil-Set ${ }^{\circledR}$ used only as curative method were selected for the next step. The other treatments, in comparison, do not have potential for use in silkworm management, once they cause damage to silkworms.

\section{Effect of alternative phytosanitary products on prevention/control of white muscardine in B. mori silkworms}

In the preventive treatment of the disease, with one application after fungal infection, there was no statistical difference in the treatment with the fungus alone. Although, in the silkworm group treated with four applications, mortality ranged from $16.7 \%$ in the treatment with Planta Clean ${ }^{\circledR}$ to $46.7 \%$ in the treatment with Agro-Mos ${ }^{\circledast}$, which did not differ from the treatment with the fungus alone (Table 3 ). Regarding confirmed mortality, there was no difference between treatments compared with the treatment with the fungus (Table 3). In the control group, there was no mortality.

A similar study showed that by spraying fungicides (Benomyl, Maneb, Daconil, Maneb + Daconil, Cerconil and Neantina) on mulberry leaves containing conidia of $B$. bassiana, mortality was reduced between 24.4 and $36.7 \%$. This result showed the effectiveness of fungicides in this form of application (CORSO; MOSCARDI, 1981).

With regard to the production of cocoons, there was no preventive action with one application; however, with four applications of the products, there was a higher production only with Planta Clean ${ }^{\circledast}$, when compared to the treatment with fungus alone (Table 3).

When the products were applied as a curative strategy, only the treatment with the product Biogermex ${ }^{\circledast}$ showed values statistically different from the ones for treatment with fungus alone, with $26.7 \%$ reduction in mortality in the group treated with just one application of the product and 25\% when treated with four applications (Table 3).

These corroborate CHAVAN et al. (2011), who also observed mortality reduction by the fungus $B$. bassiana between 21.6 and 28.3\%, when plant extracts of Argemone mexicana, Terminalia arjuna, Syzygium cumini and Annona squamosa were applied on silkworms infected with the fungus. As for confirmed mortality, there was no difference when compared to the treatment with the fungus alone (Table 3).

By contrast, it was observed that when the products were applied only once, there was a significant increase in the number 
Table 3. Total and confirmed mortality, and production of cocoons of $B$. mori silkworms infected with the fungus $B$. bassiana and treated with one and four applications of alternative phytosanitary products sprayed on mulberry leaves and on silkworms $\left(26 \pm 1{ }^{\circ} \mathrm{C}\right.$, $12 \mathrm{~h}$ photophase and relative humidity of $70 \%)$.

\begin{tabular}{|c|c|c|c|c|c|c|c|c|c|c|c|c|}
\hline \multirow{3}{*}{ Treatment } & \multicolumn{4}{|c|}{ Total mortality\% } & \multicolumn{4}{|c|}{ Confirmed mortality \% } & \multicolumn{4}{|c|}{ Production of Cocoons \% } \\
\hline & \multicolumn{2}{|c|}{ Preventive } & \multicolumn{2}{|c|}{ Curative } & \multicolumn{2}{|c|}{ Preventive } & \multicolumn{2}{|c|}{ Curative } & \multicolumn{2}{|c|}{ Preventive } & \multicolumn{2}{|c|}{ Curative } \\
\hline & $1 x$ & $4 x$ & $1 x$ & $4 x$ & $1 x$ & $4 x$ & $1 x$ & $4 x$ & $1 x$ & $4 x$ & $1 x$ & $4 x$ \\
\hline Planta Clean ${ }^{\circledR}$ & $\begin{array}{c}38.3 \pm \\
6.3\end{array}$ & $\begin{array}{c}16.7 \pm \\
5.8\end{array}$ & - & - & $\begin{array}{c}38.3 \pm \\
6.3\end{array}$ & $\begin{array}{c}15.0 \pm \\
6.9\end{array}$ & - & - & $\begin{array}{c}61.7 \pm \\
5.7\end{array}$ & $\begin{array}{c}83.3 \pm \\
5.8^{*}\end{array}$ & - & - \\
\hline Biogermex $^{\circledR}$ & $\begin{array}{c}38.3 \pm \\
9.9\end{array}$ & $\begin{array}{c}31.7 \pm \\
3.2\end{array}$ & $\begin{array}{c}70.0 \pm \\
6.9 *\end{array}$ & $\begin{array}{c}71.7 \pm \\
3.2^{*}\end{array}$ & $\begin{array}{c}33.3 \pm \\
9.4\end{array}$ & $\begin{array}{c}30.0 \pm \\
3.3\end{array}$ & $\begin{array}{l}70 \pm \\
8.6\end{array}$ & $\begin{array}{c}71.7 \pm \\
6.1\end{array}$ & $\begin{array}{c}61.7 \pm \\
9.9\end{array}$ & $\begin{array}{c}68.3 \pm \\
3.2\end{array}$ & $\begin{array}{c}30.0 \pm \\
6.9^{*}\end{array}$ & $\begin{array}{c}28.3 \pm \\
3.2^{*}\end{array}$ \\
\hline Soil-Set ${ }^{\circledR}$ & - & - & $\begin{array}{c}88.3 \pm \\
3.2\end{array}$ & $\begin{array}{c}81.7 \pm \\
3.2\end{array}$ & - & - & $\begin{array}{c}80.0 \pm \\
8.6\end{array}$ & $\begin{array}{c}75.0 \pm \\
3.2\end{array}$ & - & - & $\begin{array}{l}11.7 \pm \\
11.7^{*}\end{array}$ & $\begin{array}{c}18.3 \pm \\
3.2^{*}\end{array}$ \\
\hline Agro-Mos ${ }^{\circledR}$ & $\begin{array}{c}38.3 \pm \\
5.7\end{array}$ & $\begin{array}{c}46.7 \pm \\
8.6\end{array}$ & $\begin{array}{c}85.0 \pm \\
3.2\end{array}$ & $\begin{array}{c}91.7 \pm \\
5.0\end{array}$ & $\begin{array}{c}38.3 \pm \\
6.9\end{array}$ & $\begin{array}{c}36.7 \pm \\
4.3\end{array}$ & $\begin{array}{c}85 \pm \\
3.2\end{array}$ & $\begin{array}{c}80.0 \pm \\
10.5\end{array}$ & $\begin{array}{c}61.7 \pm \\
5.7\end{array}$ & $\begin{array}{c}53.3 \pm \\
8.6\end{array}$ & $\begin{array}{c}15.0 \pm \\
3.2^{*}\end{array}$ & $\begin{array}{c}8.3 \pm \\
5.0\end{array}$ \\
\hline B. bassiana & $\begin{array}{c}38.3 \pm \\
4.2\end{array}$ & $\begin{array}{c}38.3 \pm \\
4.2\end{array}$ & $\begin{array}{c}96.7 \pm \\
1.9\end{array}$ & $\begin{array}{c}96.7 \pm \\
1.9\end{array}$ & $\begin{array}{c}36.7 \pm \\
4.30\end{array}$ & $\begin{array}{c}36.7 \pm \\
4.30\end{array}$ & $\begin{array}{l}75 \pm \\
4.19\end{array}$ & $\begin{array}{l}75 \pm \\
4.19\end{array}$ & $\begin{array}{c}61.7 \pm \\
4.19\end{array}$ & $\begin{array}{c}61.7 \pm \\
4.19\end{array}$ & $\begin{array}{l}3.3 \pm \\
1.92\end{array}$ & $\begin{array}{l}3.3 \pm \\
1.92\end{array}$ \\
\hline
\end{tabular}

$1 \mathrm{x}$ : one application; $4 \mathrm{x}$ : four applications; *the data differ statistically from the mean value of the control (B. bassiana) by Dunnett's test ( $<<0.05)$; -: missing plot.

of produced cocoons in all treatments when compared to the treatment with the fungus alone $(26.7 \%$ in the treatment with Biogermex ${ }^{\circledast}, 11.7 \%$ in treatment with Agro-mos ${ }^{\circledast}$ and $8.4 \%$ in the treatment with Soil-Set ${ }^{\circledR}$ ). When applied for four days, the products Biogermex ${ }^{\circledast}$ and Soil-Set ${ }^{\circledast}$ also promoted an increase when compared to the treatment with fungus alone ( 25 and $15 \%$, respectively) (Table 3 ).

Biogermex ${ }^{\circledR}$ was the one who showed activity against the fungus $B$. bassiana, reducing the mortality of the silkworms in the curative strategy (Table 3).

Biogermex ${ }^{\circledast}$ is composed of bioflavonoids, i.e., molecules derived from the secondary metabolism of plants, which can act as antimicrobials. These molecules have the ability to bind to extracellular proteins of the cell walls of bacteria and fungi, inactivating them and also possibly disrupting their membranes
(TSUCHIYA et al., 1996). This is proven by the reduction of viability and decrease of colony forming units (CFU) of the fungus $B$. bassiana, as demonstrated by MAMPRIM et al. (2014).

A follow-up study to the present research is recommended, with reapplication tests or doses targeted at curative action.

\section{CONCLUSION}

Based on the results reported, it was concluded that the products Planta Clean ${ }^{\circledast}$, Soil-Set ${ }^{\circledast}$ and Agro-mos ${ }^{\circledast}$ do not have effects on the development of white muscardine in B. mori. However, Biogermex ${ }^{\circledast}$ can be promising. New tests need to be conducted, focusing on the use of this product as a curative strategy.

| | | | | | | | | | | | | | | | | | | | | | | | | | | | | | | | | | | | | | | | | | | | | | | | | | | | | | | | | | | | | | | | | | | | | | | | | | | | | | | | | | | | | | | | | | | | | | | | | | | | | | | | | | | | | | | | | | | | | | | | | | | | | | | | | | | | | | | | | | | | | | | | | | | | | | | | | | | | | | | | | | | | | | | | | | | | | | | | | | | | | | | | | | | | | | | | | | | | | | | | | | | | | | | | | | | | | | | | |

\section{REFERENCES}

AMARAL, E.; ALVES, S.B. Insetos Úteis. Piracicaba: Livroceres, 1979. 188p.

CHAVAN, J.A.; PATIL, S.J.; BHAWANE, G.P. Screening of aqueous plant extracts against Beauveria bassiana infection to 5 th instar larvae of Bombyx mori L. Journal of Medicinal Plants Research, v.5, n.16, p.3936-3939, 2011.

CHAPMAN, R.F. The Insects: Structure and Function. 4.ed. Cambridge, United Kingdom: Cambridge University Press, 1998.

CORSO, L.C.; MOSCARDI, F. Teste de fungicidas para o controle da incidência do fungo Beauveria sp. em Bombyx mori (Linnaeus,
1758). Anais da Sociedade Entomológica do Brasil, 10, n.1, p.129-133, 1981.

GALLO, D.; NAKANO, O.; SILVEIRA NETO, S.; CARVALHO, R.P.L.; BAPTISTA, G.C.; BERTI FILHO, E.; PARRA, J.R.P.; ZUCCHI, A.; ALVES, S.B.; VENDRAMIM, J.D.; MARCHINI, L.C.; LOPES, J.R.S.; OMOTO, C. Entomologia agrícola. Piracicaba: Fealq, 2002.

GUSMÃO, M.R.; PICANÇO, M.; GONRING, A.H.R.; MOURA, M.F. Seletividade fisiológica de inseticidas a Vespidae predadores do bicho-mineiro-do-cafeeiro. Pesquisa Agropecuária Brasileira, v.35, n.4, p.681-686, 2000. 
HANADA, Y.; WATANABE, J.K. Manual de criação do bicho-daseda.Curitiba: Cocamar, 1986. 224p.

KUMAR, V.; SINGH, G.P.; BABU, A.M.; AHSAN, M.M.; DATTA, R.K. Germination, penetration, and invasion of Bequveria bassiana on silkworm, Bombyx mori, causing white muscardine. Italian Journal of Zoology, v.66, n. 1, p.39-43, 1999.

KUMARI, S.S.; RAO, S.V.S.; MISRA, S.; MURTY, U.S. Antifungal activity of Turbinaria conoides and evaluation for the effective concentration against the infection of Beauveria bassiana in silkworm larvae. Research Journal of Microbiology, Índia, v.6, n.2, p. $115-123,2011$.

MAIRESE, L.A.S. Avaliação da bioatividade de extratos de espécies vegetais, enquanto excipientes de aleloquímicos. Tese (Doutorado) - Universidade Federal de Santa Maria, Santa Maria, RS, 2005.

MAMPRIM, A.P.; ALVES, L.F.A.; PINTO, F.G.S; FORMENTINI, M.A.; MARTINS, C.C.; BONINI, A.K. Efeitos de defensivos agrícolas naturais e extratos vegetais sobre parâmetros biológicos de Metarhizium anisopliae (Metsch.) Sorok. Semina: Ciências Agrárias, v.34, n.4, p.1451-1466, 2013.

MAMPRIM, A.P.; ALVES, L.F.A.; PINTO, F.G.S.; FORMENTINI, M.A.; MARTINS, C.C.; PARES, R.B. Effect of phytosanitary products on biological parameters of Beauveria bassiana (Bals.) Vuill. (Hypocreales: Cordycipitaceae). Revista de Protección Vegetal, v.29, n.2, p.128, 2014.

MARGATHO, L.F.F.; OKAMOTO, F.; ALMEIDA, A.M.; SANTOS, C.A.J.P. Avaliação quantitativa da contaminação por microrganismos no ambiente de criação do bicho-da-seda (Bombyx mori L.) na fase de chocadeira. Arquivos do Instituto Biológico, v.79, n.2, p.233-238, 2012.

MATTIELO. Planta Clean ${ }^{\circledR}$. Disponível em: <http://www.mattielo. com.br/index.php?option=com_content\&task=view\&id $=33 \& \mathrm{It}$ emid=34>. Acesso em: 10 set. 2014 .

MERTZ, N.R.; ALVES, L.F.A.; MARCOMINI, A.; OLIVEIRA, D.G.P.; SANTOS, J.C. Efeito in vitro de produtos fitossanitários naturais sobre Beauveria bassiana (Bals.) Vuill. BioAssay, v.5, n.3, p. $1-10,2010$.

MUNHOZ, R.E.F.; MENDES, T.A.; REGINATO, E.T.; NETO, G.G.; DAVIES, T.R.; BRAVO, J.P.; FERNANDEZ, M.A. A influência de cultivares de amoreira adubadas sobre características biológicas e produtivas do bicho-da-seda (Bombyx mori L.). Arquivos de Ciências Veterinárias e Zoologia da UNIPAR, v.12, n.2, p. 129-134, 2009.

NAIK, A.S.; NAIK, S.; NAIK, M.J. Screening of medicinal plant extracts against Beauveria bassiana infection to $\mathrm{V}^{\mathrm{TH}}$ intar larvae of Bombyx mori L. European Journal of Pharmaceutical an Medical Research, v.3, n.5, p.387-391, 2016.

OLIVEIRA, J.R.; FERREIRA, G.A.; OLIVEIRA, J.C.; BEZAGIO, R.C.; ZANETTI, E.A.; SIGNORINI, T.; VOLPINI, A.F.N.; TANABE, A.P.; FABRIN, T.M.C.; JAMBERSI, V.L.; CALDERON, R.N. Avaliação da dosagem de própolis pulverizada nas folhas de amoreira (Morus sp.) sobre o desenvolvimento biológico e produtivo do bicho-daseda (Bombyx mori L.) Arquivos de Ciências Veterinárias e Zoologia da UNIPAR, v.13, n.2, p.77-82, 2010.
PARES, R.B.; ALVES, L.F.A. Controle e prevenção da calcinose branca em Bombyx mori L. (Lepidotera: Bom bycidae). Arquivos do Instituto Biológico, v.83, 1-8, e0992014, 2016.

PARRA, J.R.P. Consumo e utilização de alimentos por insetos. In: PANIZZI, A.R. \& PARRA, J.R.P. Ecologia Nutricional de Insetos e suas Implicações no Manejo de Pragas. São Paulo: Manole Saúde, 1991.

PORTO, A.J.; OKAMOTO, F.; OTSUK, I.P. Estudos de cultivares de amoreira e de técnicas de manejo alimentar no desempenho do bicho-da-seda (Bombyx mori L.). Boletim da Indústria Animal, v.60, n. 1, p.71-82, 2003.

PORTO, A.J.; OKAMOTO, F.; IKUNO, A.A.; FERREIRA, V.C.A.; MARGATHO, L.F.A. Avaliação biológica e produtiva do bichoda-seda (Bombyx mori L.) alimentado com folhas de amoreira pulverizadas com extrato de Mirabilis jalapa. Arquivos do Instituto Biológico, v.72, n.4, p.445-453, 2005.

PORTO, A.J.; OKAMOTO, F. Efeito da aplicação de desinfetante sobre o bicho-da-seda (Bombyx mori L.). Boletim da Indústria Animal, v.57, n.2, p.193-199, 2000.

POTRICH, M.; ALVES, L.F.A.; BRANCALHÃO, R.C.; DALCIN, G. Entomopatógenos associados a lagartas de Bombyx mori $\mathrm{L}$. (Lepidoptera: Bombycidae) no Estado do Paraná. Arquivos do Instituto Biológico, v.74, n.4, p.363-367, 2007.

RAJAGOPAL, V.; RAMESH, H.L.; YOGANANDA MURTHY, V.N.; NINGE GOWDA, K.N. Efficacy of fungicide "Kavach" against Beauveria bassiana L. in silkworm Bombyx mori L. Journal of Applied and Natural Science, v.6, n.1, p.31-37, 2014.

RHEINHEIMER, A.R. Controle biológico e alternativo da cochonilha (Phenacoccus manihti Matile Ferrero) na cultura da mandioca (Manihot esculenta Crantz). 2010. 58f. Dissertação (Mestrado em Agronomia) - Universidade Estadual do Oeste do Paraná, Cascavel, 2010.

SILVA, E.R.L. Efeito de produtos alternativos sobre Bacillus thuringiensis subsp. kurstaki e Trichogramma pretiosum Riley (Hymenoptera: Trichogrammatidae). 2010. Tese (Dooutorado em Agronomia) - Universidade Estadual de Londrina, Londrina, 2010.

SILVA, E.R.L.; ALVES, L.F.A.; MARTINELO, L.; FORMENTINI, M.A.; MARCHESE, L.P.C.; PINTO, F.G.S.; POTRICH, M.; NEVES, P.M.O.J. Natural phytosanitary products effects on Bacillus thuringiensis subsp. kurstaki (Berliner). Ciências Agrárias, v.33, n. 1, p.2891-2904, 2012.

STATSOFT. Statistica: data analysis software system: version 7.0. Tulsa: Statsoft, 2004.

TSUCHIYA, H.; SATO, M.; MIYAZAKI, T.; FUJIWSARA, S.; TANIGAKI, S.; OHYAMA, M.; TANAKA, T.; LINUMA, M. Comparative study on the antibacterial activity of phytochemical flavanones against methicillin-resistant Staphylococcus aureus. Journal of Ethnopharmacology, v.50, n.1, p.27-34, 1996.

ZANETTI, R. Manejo e criação do bicho-da-seda. Notas de aula de Entomologia - Sericicultura. Lavras: DEN/UFLA, 2011 . Disponível em: <http://www.den.ufla.br/Professores/Ronald/Disciplinas/ Notas\%20Aula/Sericicultura\%20manejo.pdf >. Acesso em: 26 maio 2013. 